\title{
Analisis Break Even Point Penambangan Sirtu PT. Klawafun Alam Lestari Papua Barat
}

\author{
Fernando Nanlohy ${ }^{1}$, Juanita R. Horman ${ }^{2}$ \\ ${ }^{1}$ Alumni Fakultas Teknik Pertambangan dan Perminyakan, Universitas Papua \\ ${ }^{2}$ Dosen Fakultas Teknik Pertambangan dan Perminyakan, Universitas Papua
}

Received: Juli 2019; Accepted: Agustus 2019; Published: September 2019

\begin{abstract}
Abstrak
Penelitian ini bertujuan untuk menganalisis Break Even Point penambangan sirtu pada PT. Klawafun Alam Lestari Provinsi Papua Barat. Metode yang digunakan dalam penelitian ini adalah metode kuantitatif. Break Even Point menunjukkan titik dimana pendapatan setara atau sama dengan biaya yang dikeluarkan. Biaya yang dimaksudkan adalah biaya tetap dan biaya variabel. Dimana biaya tetap terdiri dari biaya kapital dan biaya tenaga kerja, sedangkan biaya variabel terdiri dari biaya produksi. Dari hasil pengumpulan data dan perhitungan maka didapatkan biaya tetap adalah sebesar Rp. 9,501,158,600 dan biaya variabel sebesar Rp. 48,972/ $\mathrm{m}^{3}$ pada harga jual sirtu sebesar Rp. 150,000/ $\mathrm{m}^{3}$. Berdasarkan analisis, Break Even Point penambangan sirtu diperoleh pada saat produksi minimum penambangan mencapai 94,045 $\mathrm{m}^{3} /$ Tahun dengan pendapatan sebesar Rp. $14,106,720,810.07 /$ Tahun.
\end{abstract}

Kata kunci: break even point, produksi minimum, biaya tetap, biaya variabel, harga jual.

\begin{abstract}
This study aims to analyze Break Even Point of mining of sirtu at PT. Klawafun Alam Lestari Provinsi Papua Barat. The method used in this research is quantitative method. Break Even Point shows the point where income is equal to cost. Intended costs are variable costs and fixed costs. Where fixed costs consist of capital costs and labor costs, while variable costs consist of production costs. From the results of data collection and calculation, the fixed cost is Rp. 9,501,158,600 and variable cost of $R p .48,972 / \mathrm{m}^{3}$, at the selling price of sirtu Rp. $150.000 / \mathrm{m}^{3}$. From the analysis, Break Even Point of mining of sirtu is obtained when the minimum mining production reaches $94,045 \mathrm{~m}^{3} /$ year with an income of $R p .14,106,720,810.07$ year.
\end{abstract}

Keywords: break even point, minimum production, fixed cost, variable cost, selling price.

How to Cite: Nanlohy, Fernando \& Horman, Juanita R. (2019). Analisis Break Even Point Penambangan Sirtu PT. Klawafun Alam Lestari Papua Barat. JFRES: Journal of Fiscal and Regional Economy Studies, 2 (2), $76-83$.

\footnotetext{
Corresponding author:

E-mail: 1fernando.nanlohy97@gmail.com, 2j.horman@unipa.ac.id
} 


\section{PENDAHULUAN}

PT. Klawafun Alam Lestari merupakan perusahaan yang bergerak di bidang pertambangan, pemecah batu dan supplier pasir dan batu (sirtu) yang terletak di Kota Sorong, Provinsi Papua Barat. Perusahaan ini mulai beroperasi pada tanggal 17 Februari 2008, dengan luas keseluruhan areal tambang sebesar $43.7 \mathrm{Ha}$. Kegiatan penambangan sirtu yang dilakukan oleh PT. Klawafun Alam Lestari terdiri dari beberapa tahapan, yaitu dimulai dari kegiatan pembongkaran, dilanjutkan dengan kegiatan pemuatan dan pengangkutan sirtu. Kuari PT. Klawafun Alam Lestari berlokasi di Jalan Sorong - Makbon, pada aliran Sungai Klasaman sepanjang $400 \mathrm{~m}$ dan Sungai Klasban sepangjang $700 \mathrm{~m}$.

Secara umum, tujuan utama sebuah perusahaan didirikan adalah untuk mendapatkan keuntungan, dimana perolehan keuntungan ini akan menjadi acuan bagi manajemen perusahaan untuk melihat kesempatan maupun peluang di masa yang akan datang.

Analisis Break Even Point merupakan salah satu metode yang sering digunakan perusahaan dalam pengambilan keputusan atas masalah yang berkaitan dengan harga, biaya, volume produksi dan penjualan serta keuntungan. Dalam hal ini kemampuan manajemen sangat diperlukan untuk menerapkan strategi perusahaan dalam menghadapi dan mengatasi persaingan dengan perusahaan lain yang sejenis dalam memproduksi sirtu, agar perusahaan dapat mencapai keuntungan semaksimal mungkin dengan penggunaan biayabiaya seminimum mungkin. Dengan demikian analisis Break Even Point dapat dipakai sebagai bahan pertimbangan bagi perusahaan dalam membuat keputusan sehubungan dengan segala kegiatan produksi untuk mendapatkan maupun memaksimalkan keuntungan, dimana untuk pencapaiannya memerlukan penerapan strategi manajemen yang tepat.

Produksi adalah suatu kegiatan untuk menciptakan dan menghasilkan atau menambah nilai guna terhadap suatu barang atau jasa untuk memenuhi kebutuhan orang atau badan (produsen). Sedangkan barang atau jasa yang dihasilkan dari melakukan kegiatan produksi disebut dengan produk. Istilah produksi berasal dari bahasa inggris to produce yang berarti menghasilkan. Sedangkan dalam arti ekonomi menurut Partadireja Ace (1985), produksi adalah kegiatan penciptaan dan penambahan atau utilitas terhadap suatu barang dan jasa.

Untuk menghasilkan barang dan jasa diperlukan faktor produksi. Faktor-faktor produksi terdiri dari alam (natural resources), tenaga kerja (labor), modal (capital), dan keahlian (skill) atau sumber daya pengusaha (enterpreneurship). Faktor-faktor produksi alam dan tenaga kerja adalah faktor produksi utama (asli), sedangkan modal dan tenaga kerja merupakan faktor produksi turunan.

\section{Faktor Produksi Alam}

Faktor produksi alam adalah semua kekayaan yang ada di alam semesta digunakan dalam proses produksi. Faktor produksi alam terdiri dari tanah, air, udara, sinar matahari, termasuk di dalamnya sumber daya pertambangan berupa mineral dan batubara.

\section{Faktor Produksi Tenaga Kerja}

Faktor produksi tenaga kerja adalah faktor produksi insani yang secara langsung maupun tidak langsung dapat menjalankan kegiatan produksi. Faktor produksi tenaga kerja sebagai faktor produksi asli. Walaupun kini banyak kegiatan proses produksi diperankan oleh mesin, namun keberadaan manusia wajib diperlukan.

\section{Faktor Produksi Modal}

Faktor produksi modal adalah faktor penunjang yang mempercepat dan menambah kemampuan dalam berproduksi. Faktor produksi ini dapat terdiri dari mesin-mesin, sarana pengangkutan, bangunan, dan alat pengangkutan.

\section{Faktor Produksi Keahlian}

Faktor produksi keahlian adalah keahlian atau keterampilan individu mengkoordinasikan dan mengelola faktor produksi untuk menghasilkan barang dan jasa, gedung pencakar langit, pembuatan pesawat terbang dan pembuatan kapal serta lain-lainnya.

Proses produksi membutuhkan waktu yang berbeda-beda, ada yang memerlukan waktu cukup lama, misalnya pembuatan kain, pembuatan televisi, dan lain-lain. Tetapi, ada juga yang memerlukan waktu singkat dan hasilnya dapat dinikmati langsung oleh konsumen seperti halnya kegiatan penambangan sirtu PT. Klawafun Alam Lestari, yang mana hasil produksinya dapat langsung digunakan sebagai bahan bangunan, baik untuk pembangunan gedung maupun perkerasan jalan dan lain sebagainya. 


\section{METODE PENELITIAN}

Metode penelitian yang digunakan dalam penelitian ini adalah metode kuantitatif. Menurut sukandarrumidi (2006), metode penelitian kuantitatif merupakan metode penelitian yang dilakukan berdasarkan data yang dikumpulkan yang dinyatakan dalam bentuk angka yang absolut dan hasilnya lebih obyektif.

Metode pengumpulan data yang digunakan dalam penelitian ini adalah:

1. Interview

Yaitu melakukan tanya jawab secara langsung kepada pihak-pihak yang berwenang untuk memberikan data dan penjelasan yang berhubungan dengan masalah yang dibahas.

\section{Dokumentasi}

Yaitu meliputi pencatatan dan pengumpulan data dengan mengambil dokumen atau data-data yang telah diarsipkan oleh perusahaan untuk kemudian dianalisis.

\section{Observasi}

Yaitu cara pengambilan data dengan melakukan pengamatan terhadap suatu objek secara cermat dan langsung di lokasi penelitian.

Metode analisis data yang dilakukan pada penelitian ini adalah:

\section{Estimasi Produksi Alat}

Menurut Partanto (2000), Secara fundamental produksi merupakan proses menghasilkan produk atau pembuatan barang dalam jumlah besarbesaran, pada umumnya dengan menggunakan mesin. Produksi alat-alat dapat dihitung dengan beberapa cara, tergantung dari ketelitian yang dikehendaki. Dalam penelitian ini digunakan perhitungan langsung yaitu suatu cara perhitungan yang memperhatikan tiap-tiap faktor yang mempengaruhi produksi untuk menentukan volume asli (pay load) yang dihasilkan oleh masing-masing alat.

$$
P=\frac{\text { Efisiensi } \times \text { Swell Factor } \times \text { Kapasitas Alat }}{\text { Waktu Siklus }}
$$

\section{Analisis Break Even Point}

Break Even Point merupakan titik dimana perusahaan berada pada keseimbangan antara jumlah pendapatan yang diperoleh dengan jumlah biaya-biaya yang telah dikeluarkan oleh perusahaan, artinya perusahaan tidak memperoleh laba maupun menderita kerugian.

Analisa Break Even Point memberikan penerapan yang luas untuk menguji tindakan-tindakan yang diusulkan dalam mempertimbangkan alternatif atau tujuan pengambilan keputusan yang lain.
Analisa Break Even Point tidak hanya semata-mata untuk mengetahui keadaan perusahaan yang break even saja, akan tetapi analisa Break Even Point akan mampu memberikan informasi kepada pimpinan perusahaan mengenai berbagai tingkat volume penjualan, serta hubungan dengan kemungkinan memperoleh laba menurut tingkat penjualan yang bersangkutan. Break Even Point dapat ditentukan secara grafis maupun matematis.

Secara grafis, Break Even Point diperoleh dari penggambaran total biaya tetap, total biaya variabel, total biaya, volume produksi dan jumlah pendapatannya (Gambar 1).

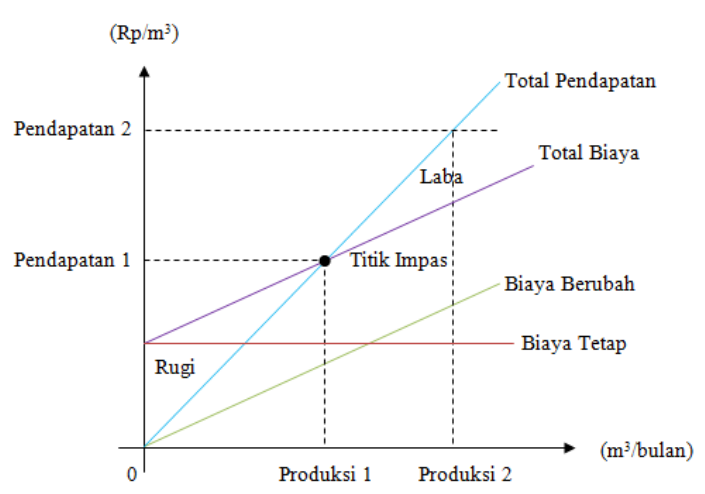

Gambar 1. Grafik Break Even Point

Secara matematis, Break Even Point diperoleh melalui turunan rumus berikut:

a. Break Even Point dalam unit $\left(\mathrm{m}^{3}\right)$

$$
\text { BEP Unit }\left(\mathrm{m}^{3}\right)=\frac{\text { Biaya tetap }}{\text { Harga jual/unit -Biaya berubah }}
$$

\section{b. Break Even Point dalam rupiah (Rp)}

$$
\text { BEP dalam } R p=\frac{\text { Biaya Tetap }}{1-\frac{\text { Biaya Berubah per Unit }}{\text { Hargalual per Unit }}}
$$

Cara ini terbukti yang paling teliti karena semua kondisi yang mungkin dihadapai sudah diperhitungkan.

Sebelumnya dikemukakan bahwa analisa Break Even Point sangat penting bagi pimpinan perusahaan untuk mengetahui hubungan antara penjualan, produksi, harga jual, biaya, rugi dan laba, sehingga memudahkan bagi pimpinan untuk mengambil kebijakan. Kegunaan BEP bagi manejer perusahaan adalah bantuannya dalam mengambil keputusan menutup usaha atau tidak (dapat memberikan informasi kapan sebaiknya usaha tersebut dihentikan saja). 
Pada tingkat break even perusahaan tidak memperoleh keuntungan karena jumlah penghasilan sama dengan jumlah biaya. Pada kondisi ini tidak berarti perusahaan harus ditutup, karena dalam keadaan break even tersebut perusahaan masih mendapatkan sisa uang (jumlah penerimaan uang lebih besar dari pada pengeluarannya). Hal ini dapat terjadi karena biaya yang terjadi dalam suatu periode pada dasarnya terdiri dari biaya tunai yaitu biaya yang memerlukan pengeluaran uang (sunk cost). Misalnya, biaya depresiasi tetap, kerugian piutang dan pengeluaran-pengeluaran lainnya yang dilakukan pada masa lalu yang manfaatnya masih dinikmati harga sekarang.

Suatu usaha harus dihentikan atau ditutup apabila penghasilan yang diperoleh tidak dapat menutupi biaya tunainya. Untuk mengetahui pada tingkat penjualan berapa suatu usaha harus dihentikan dapat dilakukan dengan menggunakan analisa Break Even Point.

Analisa Break Even Point berguna apabila beberapa asumsi dasar dipenuhi. Asumsi-asumsi tersebut adalah:

1. Biaya-biaya yang dikeluarkan perusahaan dapat dikelompokan dalam biaya variabel dan biaya tetap.

2. Besarnya biaya variabel secara total berubahubah secara proposional dengan volume produksi atau penjualan.

3. Besarnya biaya tetap secara total tidak berubah meskipun ada perubahan volume produksi ataupun penjualan.

4. Jumlah unit produk yang terjual sama dengan jumlah per unit produk yang diproduksi.

\section{HASIL DAN PEMBAHASAN}

Untuk memenuhi produksi sirtu, PT. Klawafun Alam Lestari melakukan kegiatan penambangan menggunakan alat-alat mekanis. Dalam hal ini, kegiatan pembongkaran sirtu di Sungai Klasaman dan Sungai Klasban dilakukan menggunakan Backhoe Volvo 210 B. Kegiatan pemuatan sirtu ke Dump Truck dilakukan menggunakan Backhoe yang sama. Kegiatan pemuatan dan pengangkutan sirtu ke Crushing Plant menggunakan Wheel Loader Komatsu WA 200. Kegiatan pengangkutan sirtu ke Stockpile menggunakan Dump Truck Hino 235.

\section{Estimasi Produksi Alat}

Faktor-faktor yang mempengaruhi estimasi produksi masing-masing alat mekanis adalah efisiensi kerja alat, pengembangan material (swell factor), kapasitas alat dan waktu siklus alat. Faktor-faktor tersebut diperoleh berdasarkan pengukuran langsung.

1. Produksi Bachoe Volvo 210 B

$P=\frac{25 \% \times 90 \% \times 0.9 \mathrm{~m}^{3}}{2.09 \text { menit }} \times 60$ menit $/ \mathrm{jam}$

$P=5.81 \mathrm{~m}^{3} / \mathrm{jam}$

2. Wheel Loader Komatsu WA 200

$P=\frac{36 \% \times 90 \% \times 1.5 \mathrm{~m}^{3}}{1.53 \text { menit }} \times 60$ menit $/ \mathrm{jam}$

$P=19.06 \mathrm{~m}^{3} / \mathrm{jam}$

3. Dump Truck Hino 235

$P=\frac{43 \% \times 90 \% \times 6.46 \mathrm{~m}^{3}}{18.85 \text { menit }} \times 60$ menit $/ \mathrm{jam}$

$P=7.96 \mathrm{~m}^{3} / \mathrm{jam}$

Tabel 1. Estimasi Produksi Alat Mekanis

\begin{tabular}{clr}
\hline No & \multicolumn{1}{c}{ Alat Mekanis } & \multicolumn{1}{c}{$\begin{array}{c}\text { Volume Produksi } \\
\left(\mathbf{m}^{\mathbf{3}} / \mathbf{j a m}\right)\end{array}$} \\
\hline 1 & Backhoe Volvo 210 B & 5.81 \\
\hline 2 & Wheel Loader Komatsu & 19.06 \\
& WA 200 & 7.96 \\
\hline 3 & Dump Truck Hino 235 & $\mathbf{3 2 . 8 3}$ \\
\hline \multicolumn{2}{c}{ Total }
\end{tabular}

\section{Harga Jual Sirtu}

Harga jual sirtu adalah harga yang harus dibayar oleh konsumen untuk mendapatkan sirtu. PT. Klawafun Alam Lestari menetapkan harga jual sirtu sebesar Rp. $150,000 / \mathrm{m}^{3}$. Harga jual ini adalah harga di tempat belum termasuk ongkos pengangkutan.

\section{Biaya Tetap}

Biaya tetap merupakan biaya yang secara total tidak berubah meskipun ada perubahan volume produksi atau penjualan. Biaya tetap terdiri dari biaya capital dan biaya tenaga kerja.

Tabel 2. Biaya Eksplorasi

\begin{tabular}{ccr}
\hline No & Jenis Kegiatan & Jumlah (Rp/tahun) \\
\hline 1 & Survey & $20,000,000$ \\
\hline 2 & Pemetaan & $37,500,000$ \\
\hline & Total & $\mathbf{5 7 , 5 0 0 , 0 0 0}$ \\
\hline
\end{tabular}

Tabel 3. Biaya Pembebasan Lahan

\begin{tabular}{ccr}
\hline No & Jenis Kegiatan & Jumlah (Rp/tahun) \\
\hline 1 & Tanah + Pohon & $74,200,000$ \\
\hline
\end{tabular}


Tabel 4. Biaya Perijinan

\begin{tabular}{clr}
\hline No & Jenis Kegiatan & Jumlah (Rp/tahun) \\
\hline 1 & Tempat Usaha & 500,000 \\
\hline 2 & Tanda Daftar PT & $1,500,000$ \\
\hline 3 & Pemakaian Jalan & 500,000 \\
\hline 4 & Retribusi WIUP & $2,500,000$ \\
\hline 5 & Usaha Perdagangan & $1,000,000$ \\
\hline 6 & Jaminan Kepala Desa & $3,000,000$ \\
\hline 7 & Pengangkutan dan Penggunaan Alat & $2,000,000$ \\
\hline 8 & Kepolisian & $2,500,000$ \\
\hline 9 & Mendirikan Bangunan & $1,000,000$ \\
\hline & Total & $\mathbf{1 4 , 5 0 0 , 0 0 0}$ \\
\hline
\end{tabular}

Tabel 5. Biaya Sewa Tanah

\begin{tabular}{cccc}
\hline No & & Jenis Kegiatan & Jumlah (Rp/tahun) \\
\hline 1 & Sewa Tanah & $50,000,000$ \\
\hline
\end{tabular}

Tabel 6. Biaya Fasilitas Umum

\begin{tabular}{clr}
\hline No & \multicolumn{1}{c}{ Jenis Kegiatan } & Jumlah (Rp/tahun) \\
\hline 1 & Tempat Crusher & $27,846,000$ \\
\hline 2 & Bengkel & $32,394,000$ \\
\hline 3 & Gudang Genset & $27,893,000$ \\
\hline 4 & Tempat Pompa Air & $19,631,000$ \\
\hline 5 & Mess Karyawan & $64,540,000$ \\
\hline & Total & $\mathbf{1 7 2 , 3 0 4 , 0 0 0}$
\end{tabular}

Tabel 7. Biaya Alat

\begin{tabular}{|c|c|c|}
\hline No & Jenis Kegiatan & Jumlah (Rp/tahun) \\
\hline 1 & Crushing Plant & $1,726,000,000$ \\
\hline 2 & Hino 235 & $450,000,000$ \\
\hline 3 & Hino 210 & $200,000,000$ \\
\hline 4 & Hino $130 \mathrm{HT}$ & $150,000,000$ \\
\hline 5 & Toyota Dyna $130 \mathrm{H}$ & $375,000,000$ \\
\hline 6 & Panther & $30,000,000$ \\
\hline 7 & Back Hoe Komatsu PC 200-7 & $800,000,000$ \\
\hline 8 & Back Hoe Volvo $210 \mathrm{~B}$ & $400,000,000$ \\
\hline 9 & Wheel Loader Komatsu WA 200-3 & $400,000,000$ \\
\hline 10 & Pompa Air Mitsubishi & $35,000,000$ \\
\hline 11 & Pompa Air 8 Inchi Komplit Dinamo & $25,000,000$ \\
\hline 12 & Pompa Air 4 Inchi Komplit Dinamo & $15,000,000$ \\
\hline 13 & Mesin lampu 250 KVA 8 Cyl 8 DC & $150,000,000$ \\
\hline 14 & Mesin lampu 75 KVA 4 Cyl Deutz & $60,000,000$ \\
\hline 15 & Ford Ranger Double Cabin 3.2L XLT $(4 \mathrm{x} 4) \mathrm{MT}$ & $445,900,000$ \\
\hline & Total & $5,259,900,000$ \\
\hline
\end{tabular}

Tabel 8. Total Biaya Kapital

\begin{tabular}{|c|c|c|}
\hline No & Jenis Kegiatan & Jumlah (Rp/tahun) \\
\hline 1 & Eksplorasi & $57,500,000$ \\
\hline 2 & Pembebasan Lahan & $74,200,000$ \\
\hline 3 & Perijinan & $14,500,000$ \\
\hline 4 & Sewa Tanah & $50,000,000$ \\
\hline 5 & Fasilitas Umum & $172,304,000$ \\
\hline 6 & Alat & $5,259,900,000$ \\
\hline & Total & $5,628,404,000$ \\
\hline
\end{tabular}


Tabel 9. Biaya Tenaga Kerja

\begin{tabular}{clcr}
\hline No & \multicolumn{1}{c}{ Jenis Kegiatan } & Jumlah Tenaga Kerja & Jumlah (Rp/tahun) \\
\hline 1 & Bagian Konsultasi Hukum & 1 & $49,500,000$ \\
\hline 2 & Pembantu Umum & 1 & $36,000,000$ \\
\hline 3 & Kepala Lapangan & 1 & $45,000,000$ \\
\hline 4 & Pengawas Lapangan & 1 & $45,600,000$ \\
\hline 5 & Kepala Produksi & 1 & $31,848,000$ \\
\hline 6 & Kepala Mekanik & 1 & $63,012,000$ \\
\hline 7 & Keuangan dan logistik & 3 & $131,400,000$ \\
\hline 8 & Pengolahan Sirtu & 4 & $112,272,000$ \\
\hline 9 & Operator Wheel Loader & 1 & $29,249,100$ \\
\hline 10 & Operator Back Hoe & 3 & $126,000,000$ \\
\hline 11 & Operator Dump Truck & 5 & $145,273,500$ \\
\hline 12 & Keamanan & 1 & $32,400,000$ \\
\hline 13 & Juru Masak & 1 & $25,200,000$ \\
\hline & & $\mathbf{2 4}$ & $\mathbf{8 7 2 , 7 5 4 , 6 0 0}$ \\
\hline
\end{tabular}

Tabel 10. Biaya Tetap

\begin{tabular}{|c|c|c|}
\hline No & Deskripsi Biaya & Jumlah (Rp/tahun) \\
\hline 1 & Kapital & $5,628,404,000$ \\
\hline 2 & Tenaga Kerja & $872,754,600$ \\
\hline Tot & & $9,501,158,600$ \\
\hline
\end{tabular}

\section{Biaya Berubah}

Biaya berubah merupakan biaya yang secara total berubah-ubah secara proporsional dengan volume produksi atau penjualan, atau dengan kata lain, biaya berubah per unitnya adalah tetap.

Tabel 11. Biaya Berubah Backhoe Volvo 210 B

\begin{tabular}{clrr}
\hline No & & Deskripsi Biaya & Jumlah (Rp/jam) \\
\hline 1 & Kepemilikan & & 16,666 \\
\hline 2 & Penggantian trackshoe & & 116,666 \\
\hline 3 & Reparasi & 116,666 \\
\hline 4 & Reparasi umum & 6,964 \\
\hline 5 & Bahan bakar & & 676,536 \\
\hline 6 & Minyak pelumas & 17,787 \\
\hline & & Total & $\mathbf{9 5 1 , 2 8 5}$ \\
\hline
\end{tabular}

Tabel 12. Biaya Berubah Wheel Loader Komatsu WA 200

\begin{tabular}{clrr}
\hline No & & Deskripsi Biaya & Jumlah (Rp/jam) \\
\hline 1 & Kepemilikan & & 20,237 \\
\hline 2 & Penggantian ban & & 16,666 \\
\hline 3 & Reparasi & & 16,666 \\
\hline 4 & Reparasi umum & 10,178 \\
\hline 5 & Bahan bakar & 268,968 \\
\hline 6 & Minyak pelumas & & 14,651 \\
\hline & & Total & $\mathbf{3 4 7 , 3 6 6}$ \\
\hline
\end{tabular}

Tabel 13. Biaya Berubah Dump Truck Hino235

\begin{tabular}{|c|c|c|}
\hline No & Deskripsi Biaya & Jumlah (Rp/jam) \\
\hline 1 & Kepemilikan & 19,843 \\
\hline 2 & Penggantian ban & 15,000 \\
\hline 3 & Reparasi & 15,000 \\
\hline 4 & Reparasi umum & 12,937 \\
\hline 5 & Bahan bakar & 235,536 \\
\hline 6 & Minyak pelumas & 10,780 \\
\hline & Total & 309,096 \\
\hline
\end{tabular}


Tabel 14. Total Biaya Berubah

\begin{tabular}{llr}
\hline No & \multicolumn{1}{c}{ Deskripsi Biaya } & Jumlah (Rp/jam) \\
\hline $\mathbf{1}$ & Backhoe Volvo 210B & 951,285 \\
\hline $\mathbf{2}$ & Wheel Loader Komatsu WA 200 & 347,366 \\
\hline $\mathbf{3}$ & Dump Truck Hino235 & 309,096 \\
\hline & Total & $\mathbf{1 , 6 0 7 , 7 4 7}$ \\
\hline
\end{tabular}

Biaya berubah per $\mathrm{m}^{3}$ diperoleh sebesar:

$$
\begin{aligned}
& \text { Biaya berubah }=\frac{R p \cdot 1,607,747 / \mathrm{jam}}{32 \cdot 83 \mathrm{~m}^{3} / \mathrm{jam}} \\
& =R p \cdot 48,972 / \mathrm{m}^{3}
\end{aligned}
$$

\section{Break Even Point}

Secara grafis, penentuan Break Even Point dapat dilihat pada Gambar 6. Sumbu horisontal menggambarkan produksi/unit terjual $\left(\mathrm{m}^{3}\right)$, sedangkan untuk sumbu vertikal menggambarkan biaya/pendapatan hasil penjualan (Rp). Break Even Point merupakan perpotongan antara garis total pendapatan (total revenue) dengan garis total biaya (total cost), dimana perpotongan terjadi ketika produksi (unit terjual) sebesar $94,045 \mathrm{~m}^{3} /$ tahun dan untuk biaya/pendapatan hasil penjualan pada Rp. 14,106,720,810.07.

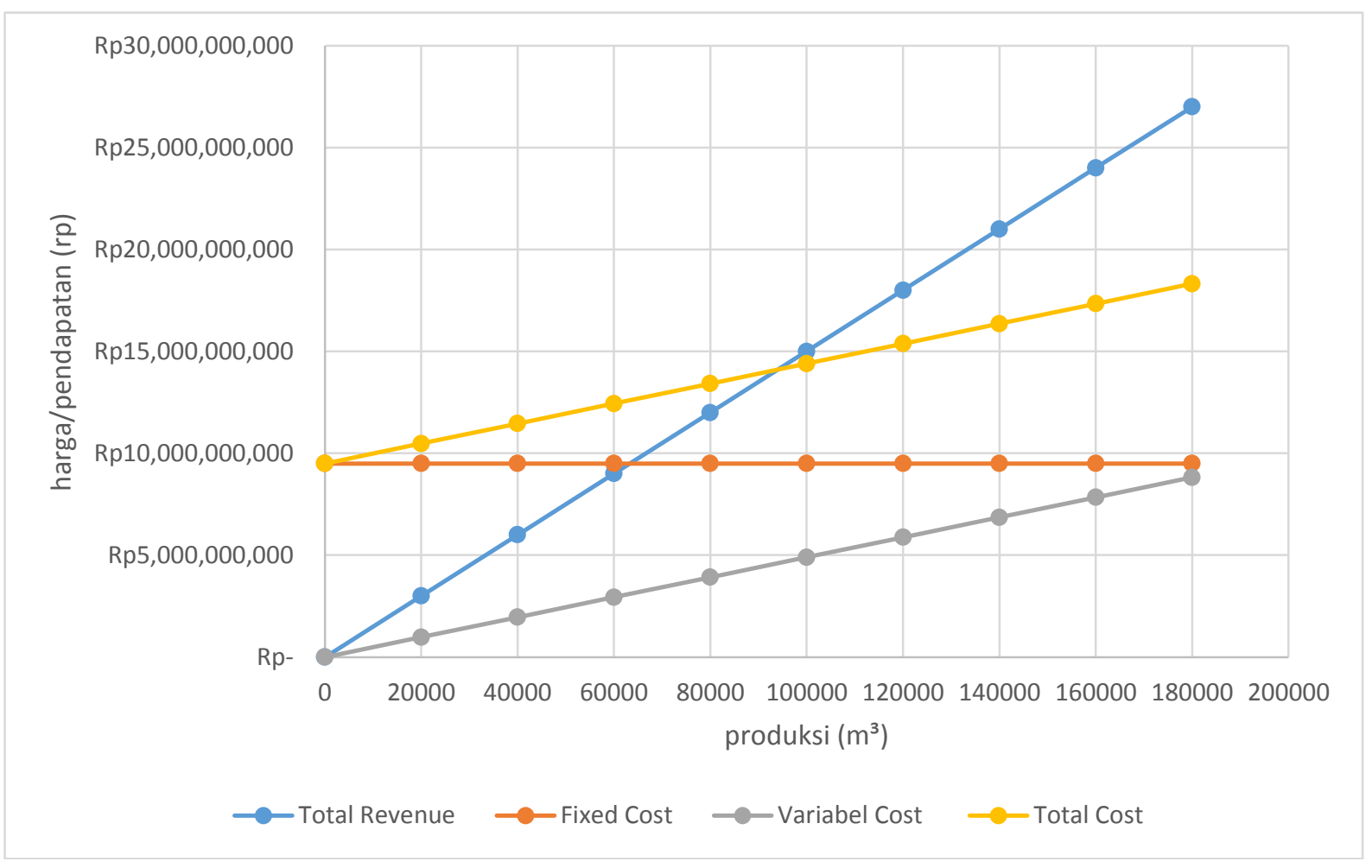

Gambar 6. Grafik Break Even Point

Perhitungan Break Even Point dengan menggunakan rumus matematis:

1. Break Even Point dalam unit $\left(\mathrm{m}^{3}\right)$

$$
\begin{aligned}
& \text { BEP Unit }\left(\mathrm{m}^{3}\right) \\
& =\frac{\text { Rp. } 9,501,158,600 / \text { tahun }}{\left(\mathrm{Rp} .150,000 / \mathrm{m}^{3}-\mathrm{Rp} .48,972 / \mathrm{m}^{3}\right)}
\end{aligned}
$$

$=94,045 \mathrm{~m}^{3} /$ tahun
2. Break Even Point dalam rupiah

BEP dalam $R p=\frac{\text { Rp. } 9,501,158,600 / \text { tahun }}{1-\left(\text { Rp. } 48,972 / \text { Rp. } 150,000 / \mathrm{m}^{3}\right)}$

$=14,106,720,810.07 /$ tahun

Berdasarkan analisis Break Even Point dalam unit $\left(\mathrm{m}^{3}\right)$ diperoleh Break Even Point 94,045 $\mathrm{m}^{3} /$ tahun, atau sebesar Rp. 14,106,720,810.07. 
Artinya PT. Klawafun Alam Lestari akan mengalami kerugian jika berproduksi di bawah $94,045 \mathrm{~m}^{3} /$ tahun.

Berdasarkan estimasi produksi menggunakan metode perhitungan secara langsung, saat ini PT. Klawafun Alam Lestari berada pada tingkat produksi 78,792 $\mathrm{m}^{3} /$ tahun, atau sebesear Rp. 11,818,800,000.00. Sehingga dapat disimpulkan PT. Klawafun Alam Lestari mengalami kerugian karena berproduksi di bawah produksi minimum Break Even Point.

Upaya peningkatan produksi alat mekanis dapat dilakukan dengan cara meningkatkan efisiensi kerja alat mekanis, yaitu persentase dari seluruh waktu yang tersedia yang dapat dipergunakan untuk kerja produktif. Berdasarkan perhitungan efisiensi kerja alat mekanis, baik Back Hoe, Wheel Loader maupun Dump Truck berada pada tingkatan efisiensi kerja buruk, yaitu kurang dari $60 \%$, sekalipun secara mekanis (physical availability) alat berada dalam kondisi baik, yaitu di atas $90 \%$.

Buruknya efisiensi kerja alat mekanis diakibatkan oleh banyaknya waktu tertunda dan terhenti selama kegiatan penambangan. Hal ini disebabkan oleh ketidakdisiplinan operator alat mekanis, seperti terlambat memulai pekerjaan, memanaskan alat di jam produksi, maupun beristirahat lebih awal. Selain itu buruknya efisiensi kerja juga disebabkan oleh ketidakserasian antara Back Hoe dan Dump Truck, dimana Back Hoe banyak menganggur karena menunggu Dump Truck.

Jika PT. Klawafun Alam Lestari meningkatkan produksi penambangan sirtu sebesar 19\% maka perusahaan baru berada pada Break Even Point. Untuk memperoleh laba/keuntungan sebesar 20\%, PT. Klawafun Alam Lestari harus meningkatkan produksi penambangan sirtu sebesar $43 \%$.

\section{KESIMPULAN}

1. Saat ini PT. Klawafun Alam Lestari sedang merugi.

2. Break Even Point unit $\left(\mathrm{m}^{3}\right)$ untuk sirtu sebesar 94,045 $\mathrm{m}^{3} /$ Tahun.

3. Break Even Point rupiah untuk sirtu sebesar Rp.14,106,720,810.07/Tahun.

4. Untuk memperoleh laba/keuntungan sebesar 20\%, PT. Klawafun Alam Lestari harus meningkatkan produksi penambangan sirtu sebesar $43 \%$ dari produksi saat ini.

\section{DAFTAR PUSTAKA}

Ace Partadireja. 1985. Pengantar Ekonomi. Universitas Islam Indonesia.

Ahyari. 2002. Manajemen Produksi Perencanaan. Yogyakarta.

Indonesianto Yanto. 2005. Pemindahan Tanah Mekanis. UPN "Veteran" Yogyakarta.

Juanita R. Horman. 2015. Penentuan Produksi Sirtu Berdasarkan Titik Impas Penambangan Pada PT. Pulau Lemon Manokwari. Jurnal ISTECH Vol 7 No 1. Jurusan Teknik Universitas Papua.

Pramestyas Alini Ratih. 2010. Analisis Break Even Point Sebagai Alat Bantu Manejemen Dalam Perencanaan Penjualan. Fakultas Ekonomi Dan Manejemen Institut Pertanian Bogor.

Soeharno. 2006. Ekonomi Manajerial. Yogyakarta.

Sukandarrumidi. 2006. Metodologi Penelitian. Gadjah Mada University Press. Yogyakarta.

Prodjosumarto Partanto. 1995. Pemindahan Tanah Mekanis. ITB Bandung. 